C. BAttilocchio,* F. Feist, A. hafner, M. Simon, D. N. Tran, D. M. AllWood,

D. C. BLAKEMORE, S. V. LEY* (UNIVERSITY OF CAMBRIDGE AND PFIZER WORLDWIDE MEDICAL CHEMISTRY, CAMBRIDGE, UK)

Iterative Reactions of Transient Boronic Acids Enable Sequential C-C Bond Formation

Nature Chem. 2016, 8, 360-367.

\title{
Sequential C-C Bond Formation via Allylic and Benzylic Boronic Acids
}

Synthesis of a valid precursor to bakuchiol:<smiles>C=CC(C)(/C=C/c1ccc(O)cc1)CCC=C(C)C</smiles>

Sequential reaction and final reaction with aldehydes:<smiles>[R]CCCCC(C)C(C)C</smiles><smiles>[R]C(=C)CC=[W]</smiles><smiles>[R]C=CC(Br)C([R])C(C)C</smiles>

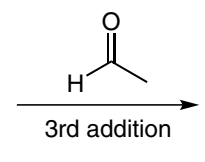<smiles>CC(O)CC=CCC(C)C(C)C</smiles><smiles>COc1cccc(C(/C=C/C(C)(CCC=C(C)C)C(O)c2ccc(F)cc2)C(O)c2ccc(C(C)C)cc2)c1</smiles>

Significance: Allylic and benzylic boronic acids, prepared in situ from flow-generated diazo compounds and stable boronic acids, were used in sequential $\mathrm{C}-\mathrm{C}$ bond formation reactions. For example, the sequential reaction of (4-methoxyphenyl)boronic acid with a flow-generated diazo compound and acetaldehyde gave a precursor of the natural product bakuchiol in 60\% yield from a single operation.
Comment: The authors have recently reported the reaction of arylboronic acids with flow-generated diazo compounds (Chem. Sci. 2015, 6, 1120). The current paper describes the sequential formation of up to three $\mathrm{C}-\mathrm{C}$ bonds. 